\title{
Power Sector in India: Issues, Challenges \& Prospects
}

\author{
Anupam Sharma ${ }^{1}$, Deepak P. Chodankar ${ }^{2}$, Jayesh G. Priolkar ${ }^{3}$ \\ PG Student, Electrical \& Electronics Department, Goa College of Engineering, Farmagudi, India ${ }^{1,2}$ \\ Assistant Professor, Electrical \& Electronics Department, Goa College of Engineering, Farmagudi, India ${ }^{3}$
}

\begin{abstract}
Prior to its restructuring in the year 2003, for decades the Indian Power Sector was not allowed to function autonomously, had poor technical capabilities, huge political interference and a large workforce. Transmission and Distribution losses in some State Electricity Boards amounted to as high as 40 to $50 \%$, resulting in massive energy shortages while electricity tariffs were low and populist. Rate of Return was never allowed to be $3 \%$ on capital thus violating Act of parliament. All these factors resulted in poor technical and financial performance of State Electricity Boards. The Reforms in electricity sector focused on organizational changes, brought competition in Generation, Transmission \& Distribution Sectors and introduced Regulations. Strong and consistent energy policy is critical to cope up with the challenges and issues in Power Sector. Various policy reforms for accelerated development of Indian Power sector has shifted Indian power sector from Government owned systems towards Market based control systems, offering choices to public and private sectors. Pricing mechanism in policy has to ensure financial viability in sector and send proper signal to investors. Coal, Oil \& Gas, Nuclear, Renewable and Hydro sectors need clear policy measures for the growth of and to attract private investments in these sectors. Market based system provides choice for buying power from different entities, the price is decided by interaction of demand and supply, hence pricing becomes competitive. The various policy measures taken have ensured financial viability of the sector. The Attracted investments also have ensured protection of consumer interests \& promoted transparency and efficiency in operation and governance. Indian Power sector still needs to undergo a lot of institutional changes, introduce energy policies and emulate the organizations with global practices. This paper reviews various Concerns, Challenges and Prospects in Power Sector.
\end{abstract}

Keywords: Indian Power Sector, State Electricity Board, Supply and Demand, Competitive Markets.

\section{INTRODUCTION}

India is the world's largest democracy and second most populous country with more than 1.3 billion individuals on the earth [1]. In South Asian subcontinent, India is surrounded by the Bay of Bengal on the southeast, Arabian Sea on the southwest and Indian ocean [2].

Energy is the flow of electricity. Being a strategic commodity, it plays an important role in economic development of the country. In the current year, Indian economy will continue to grow at more than $7 \%$. For proper planning, energy statistics play a significant role for policy makers in India \& also help them in decision making [3]. In order that India can progress towards sustainable development, a clear analysis of the relationship amongst climate, land, energy and water use is essential. [4]. Availability of energy, land and water are some of the most important resources of India [5]. To supply base load electricity, India heavily depends on coal \& holds third rank after China \& USA in terms of coal fired power generation [6]. True and accurate cost estimation of electricity generation is very complex topic [7]. To reduce energy intensity in Indian economy, the Government of India under the provision s of Energy Conservation Act 2001, has set up Bureau of Energy Efficiency (BEE) on $1^{\text {st }}$ march 2002 [8]. In 2003, Central Electricity Regulatory Commission armed with the provisions in Electricity Act came out with the action plan of regulating the central power generation utilities and to transform Indian power sector [9]. Competition is one of the dominant factor in electric power industry [10]. The Independent Power Producer Association of India provides an apolitical and agenda free platform for the discussion and examination of regulatory, financial, strategic and policy issues critical to the development of infrastructure \& energy sector within India [11].

This paper deals with various issues and challenges faced by the Indian power sector and how to enable this world's largest democratic nation to become globally competitive as far as infrastructure \& energy is concerned, with an objective to address the opportunities of an ever-liberalizing Indian economy. Paper is organised as follows. Section two and three address concerns and challenges faced by the Indian power sector, section four discusses the opportunities present in Indian power sector \& section five concludes the paper. 


\section{ISO 3297:2007 Certified}

Vol. 5, Issue 6, June 2017

\section{ISSUES IN INDIAN POWER SECTOR}

World third largest producer and fourth largest consumer of electricity is India [12]. As of $31^{\text {st }}$ march 2017, India has an installed Generation capacity of $319.60 \mathrm{GW}$ [13].

\section{A. Issues in power generation}

NTPC is the largest Thermal Power Generation company in India with the power generating capacity of 51,410 MW at present and with a long term plan to become 128000 MW company by the year 2032 [14]. The issue in coal sector is lack of private investment and low plant load factor due to shortage and poor quality of coal supplied [15]. The low utilization rate of operational plants reduce the volume of generated capacity \& also undermine the financial performance of generating companies. Coal India limited and The Singareni Collieries Company limited have a monopoly on coal production. Gestation period, pollution and environmental concerns also impacts thermal power generation in India.

\section{B. Issues in power transmission}

Power Grid Corporation of India limited is the India's largest electric power transmission utility and also the central transmission utility of India [17]. As on $31^{\text {st }}$ march 2017, the total transmission capacity is $75050 \mathrm{MW}$ of the interregional links. Power System Operation Corporation limited manage the national \& regional grids through latest technology from National Load Dispatch Centre [18]. The issues are transmission tariff design, right of way, Investment in the sector and allocation of transmission corridor to exchange the power [19].

C. Issues in power distribution

Reduction of distribution losses is a major issue in Indian Power sector. One of the most important features of Electricity Act 2003 is the Open Access wherein, consumer and distribution companies have the freedom to buy electricity directly from the generating companies. A lot of awareness is required to educate the consumers about the open access. Installation of availability based tariff, availability of independent feeder \& automation in power distribution are the critical issues in distribution sector. Reduction of aggregate technical and commercial losses, improved power quality supply, improved customer satisfaction, strengthening of distribution network, provision for $100 \%$ metering and introduction of competition through Open access are some of the salient features of restructured power system [20].

\section{III.CHALLENGES IN INDIAN POWER SECTOR}

A. Demand supply gap

Indian power sector offers enormous prospects for foreign investors [21]. India's Energy-GDP elasticity of 0.8 reflects the industry movement beside with economic growth [22]. By 2018, India will overtake China to become world fastest growing economy [23]. In the next 20 years, India will need an additional $869 \mathrm{GW}$ [24].

Table 1: Shortage Condition in India in terms of Energy \& Peaking availability (Source: LGBR 2016-2017 CEA)

\begin{tabular}{|c|c|c|}
\hline & Energy (MU) & Peak (MW) \\
\hline Requirement & $1,114,408$ & 153,366 \\
\hline Availability & $1,090,851$ & 148,463 \\
\hline Shortage & -23557 & -4903 \\
\hline$\%$ & $-2.1 \%$ & $-3.2 \%$ \\
\hline
\end{tabular}

Table 2: Actual Power Supply Condition (Source: LGBR 2016-2017 CEA)

\begin{tabular}{|l|l|l|l|}
\hline Region & Requirement & Availability & Surplus(+) Deficit(-) \\
\hline Northern & 340,475 & 324,009 & $-4.8 \%$ \\
\hline Western & 346,767 & 345,967 & $-0.2 \%$ \\
\hline Southern & 288,025 & 283,494 & $-1.6 \%$ \\
\hline Eastern & 124,653 & 123,646 & $-0.8 \%$ \\
\hline All India & $1,114,408$ & $1,090,851$ & $-2.1 \%$ \\
\hline
\end{tabular}

Power Finance Corporation limited is the financial backbone of Indian power sector, provide competitive \& affordable services and products [25]. Under the plug and play model, Government of India is planning to set up few Ultra Mega Power Projects of about 4000 MW capacity each, to achieve higher level of fuel efficiency under tariff based 
competitive bidding. Special purpose vehicle set up by Power Finance Corporation for each Ultra Mega power project are responsible for carrying out various activities such as allocation of coal blocks for pit- head projects, obtain clearance from State Pollution Control board etc. [26].

\section{B. Huge Transmission \& Distribution losses}

Indian government targets cut down transmission and distribution losses to $15 \%$ by 2019 [27]. Transmission and Distribution loss also includes Pilferage/theft [28]. In 2015, Indian government designed Deen Dayal Upadhyaya Gram Jyoti Yojna scheme to provide Continuous uninterrupted power supply to all the villages in India and to improve the quality and reliability of power supply. As of march 2017, 593184 villages have been electrified out of 597,464 census villages [29]. Indian government launched Integrated Power Development Scheme to focus on improvement of transmission and distribution networks in India. All distribution companies including private distribution companies and state power departments can get financial assistance under this scheme. It is basically a new version of Restructured Accelerated Power development Programme. Power Finance Corporation is the Nodal agency for this this scheme [30].

\section{Approval and License}

Biggest challenge that is faced by Indian power sector is the land acquisition. A number of government bodies needs to be contacted for the clearances. Currently Foreign direct investment is not allowed in nuclear segment. To set up new power plants, there is no requirement of licenses and it is done through a transparent bidding process, Power procurement is permitted. Only 49\% Foreign Direct Investment and Foreign Institutional Investor is permissible for Power Exchange [31]. Energy companies in India need to be improved to create a well- functioning \& financially viable Electricity market. Effective implementation of energy policies should be increased to assure timely completion of energy projects. Based on market principles, India should complete unfinished reforms on its power sector. A greater degree of liberalization in Indian power sector allow Foreign Direct Investment along the entire value chain that is Generation, Transmission \& Distribution. Building up the infrastructure that is grossly insufficient, perennial shortage of fuel and inherent financial weakness of state owned power companies are some of the key challenges faced by the Indian power sector. To increase the domestic production, renewable energy sector as well as the oil \& gas sector vie for strong private investments. Coal sector is least open to private investments. Central government exclusively controls nuclear sector [32].

\section{IV.OPPORTUNITIES IN INDIAN POWER SECTOR}

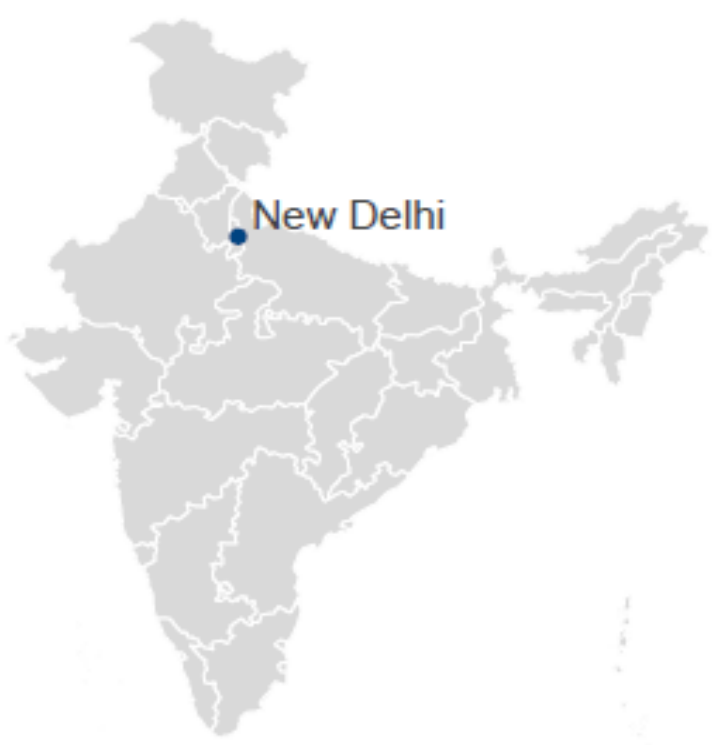

Table 3: India's Overview

\begin{tabular}{|c|c|}
\hline Capital & New Delhi \\
\hline Area & $3,287,000$ Sq. Km \\
\hline Form of state & Federal Republic \\
\hline Official Language & Hindi \& English \\
\hline
\end{tabular}


As on 31 July 2016, India's renewable energy contribution stands at $44.8 \mathrm{GW}$ which include 8 GW of solar power \& $27.4 \mathrm{GW}$ of wind power. By 2022, Indian government plans to achieve $175 \mathrm{GW}$ of renewable power which includes $100 \mathrm{GW}$ of solar power, $60 \mathrm{GW}$ of wind power, $10 \mathrm{GW}$ from Biomass power \& $5 \mathrm{GW}$ from small hydro power. There is a large scope for development of renewable energy sector taking into account the favourable policies by government of India for this sector. If this sector is developed the issues related to demand supply gap can be overcome in coming years \& India can become power surplus country.
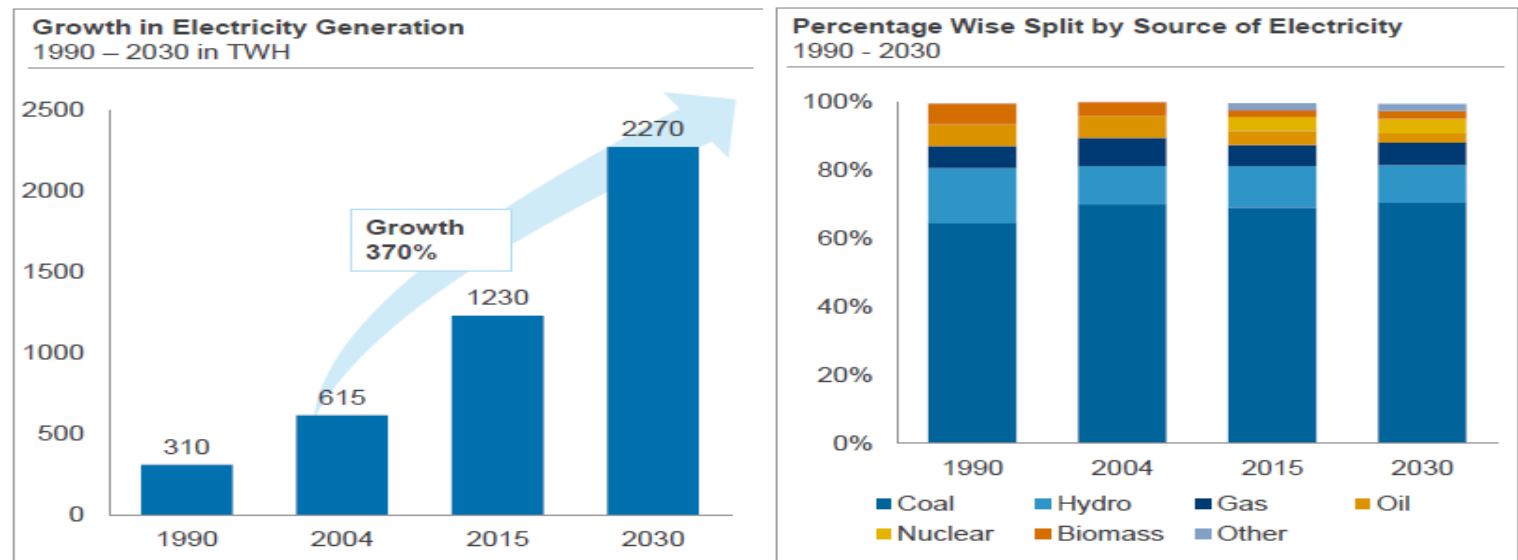

Fig.1. Indian Power Sector Overview
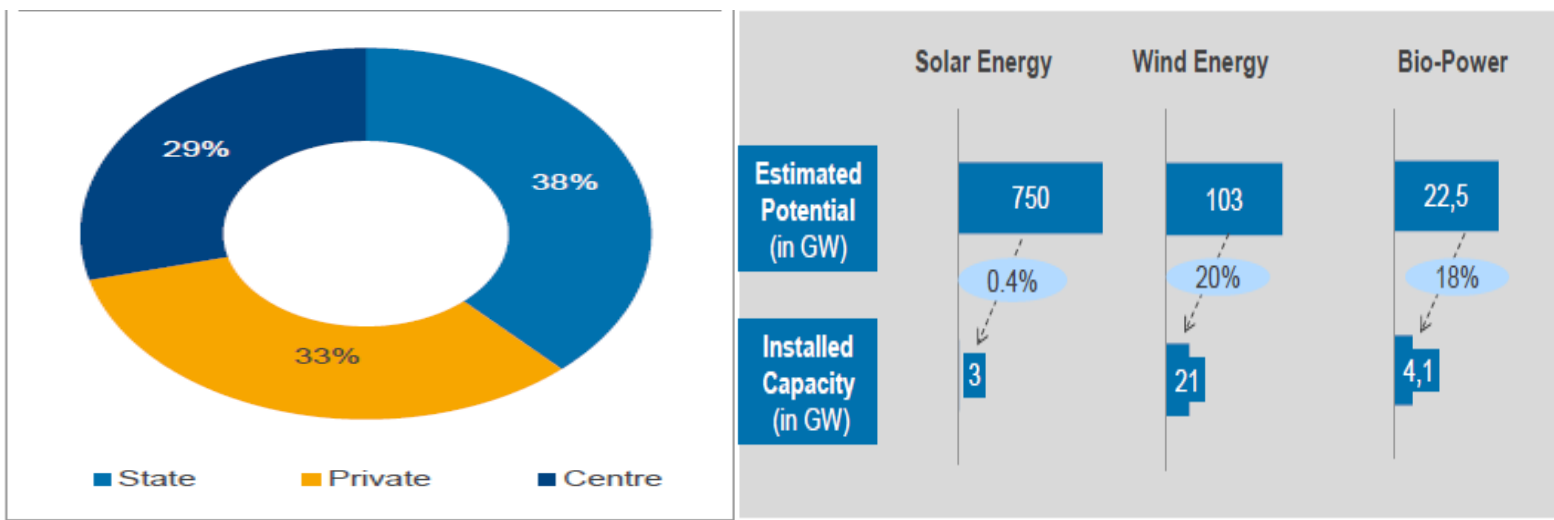

Fig.2. Present Power generation capacity \& Estimated future generation potential for renewable in India.
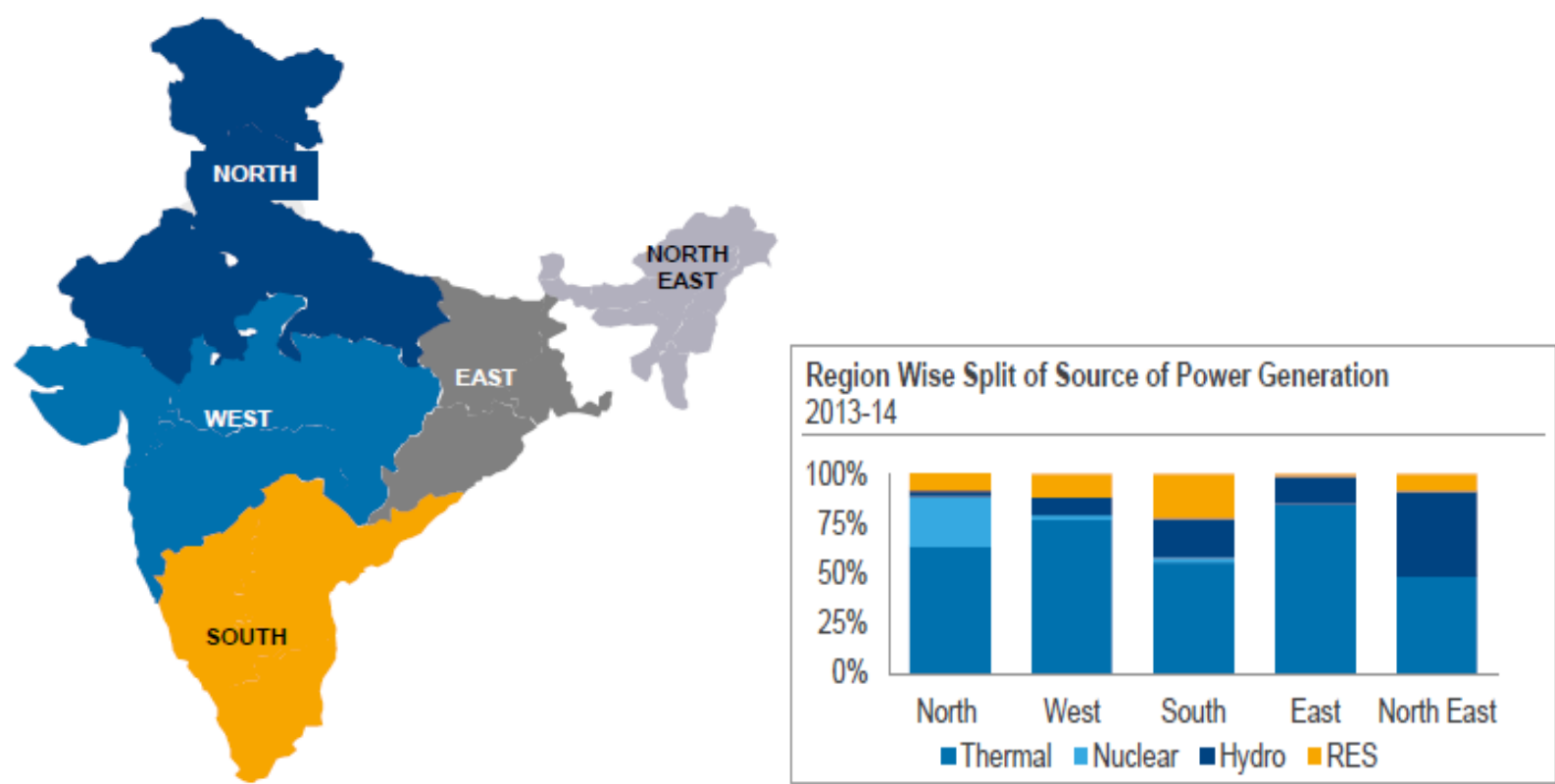

Fig.3. Load dispatch centre in India along with power generation capacity 

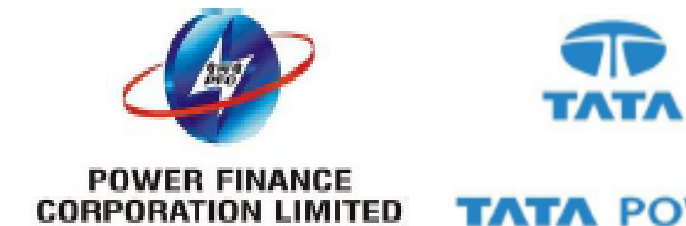

RELIANCE CORPORATION LIMITED

TATA POWER
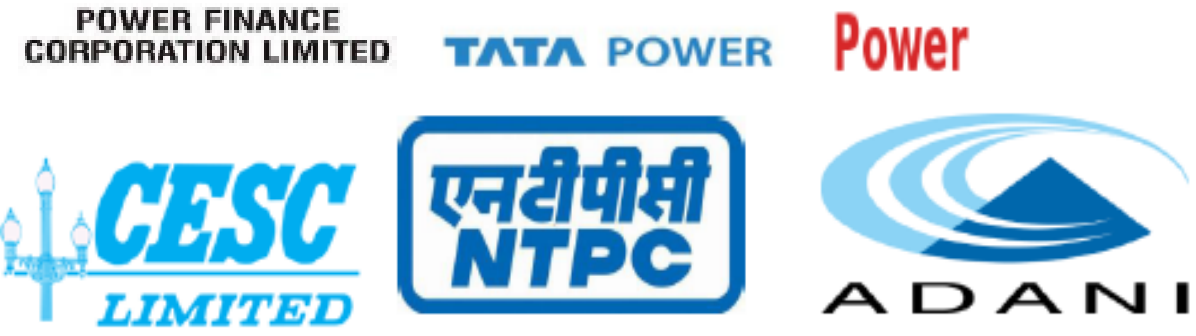

Power Grid Coponotion of Indiz

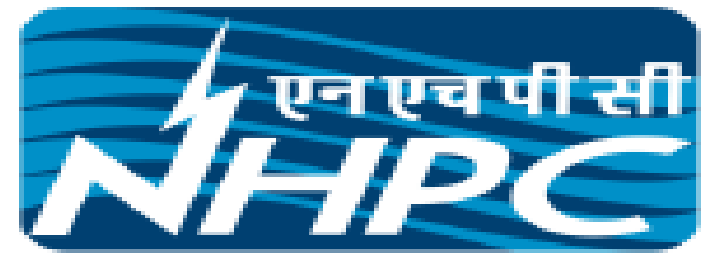

CLP@中電

\section{CLP Holdings (Hong Kong)}

GE Energy (USA)

\section{KOSEF') garsuez}

Kosep (South Korea)

GDF SUEZ (France)

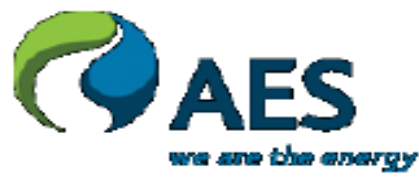

AES (USA)

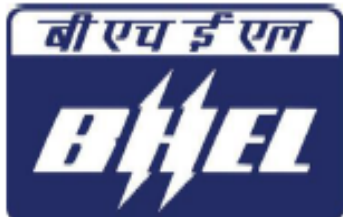

*The above logos and trademarks are the properties of the respective companies

Fig.4.Major Players \&Foreign Investor’s in Indian Power Sector

$100 \%$ foreign direct investment is permitted under automatic route for distribution \& generation of renewable energy. In 2006 Ministry of New \& Renewable Energy came into existence for all matters related to renewable energy [33]. Indian Renewable Energy Development Agency Limited was established in 1987 to promote \& develop financial assistance for projects related to renewable energy [34]. Most part of India receive good solar radiation $4-7 \mathrm{kWh} / \mathrm{sq}$. $\mathrm{m} / \mathrm{day}$ so there is scope for development of this sector in most of the states of India. Indian government announced Jawaharlal Nehru Solar mission to promote solar energy technology for clean \& green power [35].
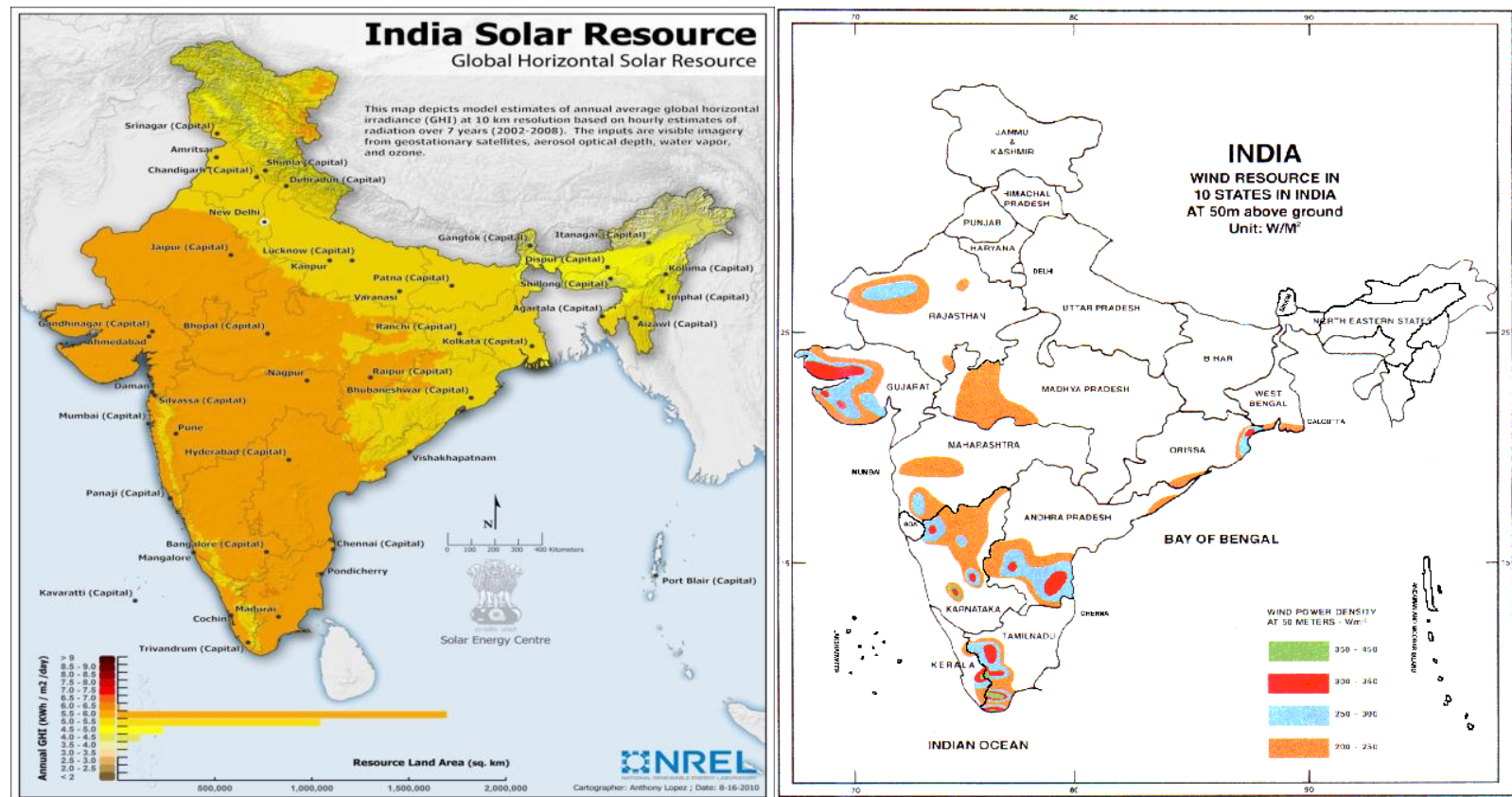

Fig. 5. Status of Solar and wind in India 


\section{International Journal of Innovative Research in Electrical, Electronics, Instrumentation and Control Engineering}

ISO 3297:2007 Certified

Vol. 5, Issue 6, June 2017

\section{CONCLUSION}

As it stands now, the Indian Power Sector is wrought with issues and challenges but at the same time there are plenty of opportunities that beckon. The numerous initiatives announced by the government, as well as those being implemented have started yielding results towards Energy Rich India though the pace of development leaves a lot to be desired. The next five years are going to be very crucial for the Power Sector in India. The targets set for achieving self-sufficiency in energy needs of the country are quite high and the time lines set for the same are too stiff. However with perfect planning, clinical execution, complete transparency and committed approach, the magic figure of $1000 \mathrm{GW}$ with a sizeable contribution of about $15 \%$ from the Renewable sources, is not only achievable but can be surpassed.

\section{REFERENCES}

[1] www.ind.gov.in

[2] www.indiapopulation2017.in

[3] www.mospi.gov.in

[4] www.un.org

[5] www.osemosys.org

[6] www.worldenergy.org

[7] www.ren21.net

[8] www.beeindia.gov.in

[9] www.cercind.gov.in

[10] www.epsa.org

[11] www.ippai.org

[12] www.bp.com

[13] www.cea.nic.in

[14] www.ntpc.co.in

[15] www.coalindia.in

[16] www.scclmines.com

[17] www.powergridindia.com

[18] www.posoco.in

[19] www.powerexindia.com

[20] www.planningcommision.gov.in

[21] www.eia.gov

[22] www.financialexpress.com

[23] www.eiu.com

[24] www.bridgetoindia.com

[25] www.pfcindia.com

[26] www.energitica-india.net

[27] www.business-standard.com

[28] www.teriin.org

[29] www.ddugjy.gov.in

[30] www.ipds.gov.in

[31] www.dipp.nic.in

[32] www.iea.org

[33] www.mnre.gov.in

[34] www.ireda.gov.in

[35] www.seci.gov.in 